九州大学学術情報リポジトリ

Kyushu University Institutional Repository

\title{
pH-Dependent Continuous Lactic Acid Fermentation by Lactococcus lactis I0-1 Using Hydrolyzed Sago Starch.
}

Nolasco-Hipolito, Cirilo

Laboratory of Microbial Technology, Division of Bioresource and Bioenvinllunental Sciences, Graduate School, Kyushu University

Crabbe, Edward

Laboratory of Microbial Technology, Division of Bioresource and Bioenvinllunental Sciences, Graduate School, Kyushu University

Kobayashi, Genta

Laboratory of Microbial Technology, Division of Bioresource and Bioenvinllunental Sciences, Graduate School, Kyushu University

Sonomoto, Kenj i

Laboratory of Microbial Technology, Division of Bioresource and Bioenvinllunental Sciences, Graduate School, Kyushu University

他

https://doi.org/10.5109/24339

出版情報：九州大学大学院農学研究院紀要. 44 (3/4)，pp.367-375，2000-02. Kyushu University バージョン：

権利関係 : 


\title{
pH-Dependent Continuous Lactic Acid Fermentation by Lactococcus lactis IO-1 Using Hydrolyzed Sago Starch.
}

\author{
Cirilo Nolasco-Hipolito, Edward Crabbe, Genta Kobayashi, \\ Kenji Sonomoto, and Ayaaki Ishizaki*
}

\author{
Laboratory of Microbial Technology, Division of Bioresource and Bioenvironmental Sciences, \\ Graduate School. Kyushu [iniversity, 6 10-1 Hakozaki, Higashi-ku, \\ Fukuoka 812-8581, Japan \\ (Recuved October 28, 1999 and accepted November 5, 1999)
}

\begin{abstract}
High dilution rate and high cell density continuous lactic acid production by Lactococcus lactis 10-1 in hydrolyzed sago starch medium was investigated using a pll-dependent feed system coupled with cross flow filtration and turbidity control. Lactatc production and productivity were dependent on cell density, dilution rate and feed glucose concertration. A1. a cell concentration of $15 \mathrm{~g} / /$ and a feed glucose concentration of $50 \mathrm{~g} / \mathrm{l}$, volumetric lactate productivitics of $14.9,23.5$ and $33.0 \mathrm{~g} \cdot l^{1} \cdot \mathrm{h}^{1}$ werc obtaincd at dilution rates of $0.35,0.5$ and $1.1 \mathrm{~h}^{1}$ respectively. The respective residual glucose concentrations in the permeate were 0.8 , 1.0 and $3.7 \mathrm{~g} / \mathrm{l}$. On increasing the feed glucose concentration to $64 \mathrm{~g} / \mathrm{l}$, volumetric lactate productivities of 12.4 and $32.3 \mathrm{~g} \cdot \mathrm{l}^{-1} \cdot \mathrm{h}^{-i}$ at dilution rates of 0.21 and $0.70 \mathrm{~h}$ ' were obtained while the respestive residual glucose concent rations in permegte were 2.7 and $12.2 \mathrm{~g} / \mathrm{l}$.
\end{abstract}

\section{INTRODUCTION}

Over the last decade, lactic acid production has gained considerable attention because, besides its conventional applications in the food and pharmaceutical industries (Yin et al, 1987; Marshall, 1987; Atkinson and Mavituna, 1991) it is a raw material for the synthesis of polylactic acid (PLA), an essential biodegradable plastic material, oxygenated chemicals, green chemical/solvents, and plant/growth regulators (Datta et al, 1995). However, the high cost of lactic acid production, either petrochemically or fermentatively, has been the bottleneck for practical application. Presently, fermentation accounts for half of the world lactic acid production (Vick Roy, 1985). One advantage of this bioprocess is that carbon dioxide is not released, making this process environmentally friendly (Ishizaki, 1997). Therefore, there has been a lot of interest in the development and improvement of the kinetics of fermentative lactic acid production.

To this end, it has been attempted to replace batch fermentation with continuous processes to reduce end-product inhibition and improve lactate productivity. Further improvements in productivity have been achieved using higher cell densities, employing cell immobilization (Senthuran et al, 1997; Mehaia and Cheryan, 1987a; Zayed and Winter, 1995), and by using cell-recycling modules (Ohleyer et al, 1985a; Bibal et al, 1991; Xavier, et al, 1995), different fermentation feedstocks and different lactate-producing strains (Linko and Janavainen, 1996; Chatterjee et al, 1997; Hofvendahl and Hahn-hägerdal, 1997, Moldes et al, 1999). For example, productivities between 56 and $88 \mathrm{~g} \cdot l^{-1} \cdot \mathrm{h}^{-1}$ have been reported in lactose-based media using different Lactococci and Lactobacilli (Ohleyer, et al, 1985b; Mehaia and Cheryan, 1987b). However they were 
obtained with low specific lactate productivities. Additionally, some fermentation systems have incorporated lactate recovery units such as electrodialysis (Boniardi et al, 1997; Vonktaveesuk et al, 1994), extractive fermentation (Ye and Shimizu, 1996) and ion exchange resins (Evangelista et al, 1994) to increase both lactate production and productivity. Nevertheless, an efficient modern process for lactic acid fermentation that produces organic acid for industrial purposes has not yet, been established.

Like any industrial organic acid or solvent fermentation, the basic economic factors remain the choice, and cost, of the substrate and the cost of recovery (or downstream processing). Substrates/feedstocks that would reduce the processing cost would greatly enhance the competitiveness of fermentative lactate production. Sago starch obtained from the processing of the sago palm is cheap and its possible harvest have been reported to be $25 \mathrm{t} / \mathrm{h}$ year (Ishizaki, 1997). Work in our laboratory has established a method for the efficient enzymatic hydrolysis of sago starch to glucose. In this study, we report on the use of hydrolyzed sago starch to produce lactic acid in batch and continuous cultures. We report on the improvements made in the productivity of lactic acid fermentation employing $\mathrm{pH}$-dependent substrate feeding combined with cross flow filtration and turbidity control of the cell concentration using hydrolyzed sago starch as the substrate.

\section{MATERIAL AND METHODS}

Microorganism and growth medium The microorganism was Lactococrus lactis IO-1 (Ishizaki et al, 1990). Stock cultures were maintained at $4{ }^{\circ} \mathrm{C}$ on thioglycolate medium (Difco Laboratories, Detroit, MI). The growth medium, per liter of dcionized water, consisted of: glucose, $10 \mathrm{~g}$; polypeptone, õ g: ycast extract (I)ifco Laboratories, Detroit, $\mathrm{MI}), 5 \mathrm{~g}$; and $\mathrm{NaCl}, 5 \mathrm{~g}$.

Media Sago starch was obtained through the University of Sarawak, Malaysia (TNIMAS), and stored at room temperature until use. The hydrolysis procedure has been described in the section on sago starch hydrolysis. Batch culture experiments were conducted using both glucose obtained from the sago starch and technical grade glucose as carbon source, by increasing the glucose concentration of the growth medium until $75 \mathrm{~g} / \mathrm{l}$. Continuous fermentation experiments were carried out using sago glucose only. An initial glucose concentration of $30 \mathrm{~g} / \mathrm{l}$ was used and the respective concentrations of polypeptone and yeast extract doubled to $10 \mathrm{~g} / \mathrm{l}$ each in order to increase cell density. The glucose concentration of the feed medium was varied between 50 and $64 \mathrm{~g} / l$.

Sago starch hydrolysis Two enzymes, Kleistase T5, a thermostable amylase from Bacillus subtilis, purchased from Daiwa Kasei Co., Lud. (Osaka) and glucozyme, from Rhizopus delemar, purchased from Amano Pharmaceutical (o., Ltd. (Nagoya) were used. Their respective enzymatic activities as defined by the manufacturers were $5,000 \mathrm{AU} / \mathrm{g}$ and $4,200 \mathrm{AL} / \mathrm{g}$. Starch hydrolysis was carried out in accordance with a method described previously (Tripetchkul et al, 1992) as follows. $30 \mathrm{~g}$ of starch was suspended in $100 \mathrm{~cm}^{3}$ of tap water. $\mathrm{pH}$ was adjusted to 6.5 by adding $1 \mathrm{M} \mathrm{NaOH}$. Liquefaction was carried out by adding $0.2 \%(\mathrm{v} / \mathrm{v})$ of Kleistase T5 to the slurry at $\mathrm{pH} 6.0$; incubating at $95^{\circ} \mathrm{C}$ for $2 \mathrm{~h}$, heating to $130^{\circ} \mathrm{C}$ for $10 \mathrm{~min}$, and then adding $0.1 \%$ of Kleistase 
$\mathrm{T} 5$ to the slurry at $\mathrm{pH} 6.5$ and incubating for $1 \mathrm{~h}$ at $95^{\circ} \mathrm{C}$. Saccharification was carried out by adding 8 units of glucozyme per gram of starch al $\mathrm{pH} 5.5$ and incubating at $50^{\circ} \mathrm{C}$ for $24 \mathrm{~h}$.

Cell recycling In this study, two hollow fiber cartridges (MICROZ $\Lambda$ PSP-103 from $\Lambda$ sahi Kasei Co., Ltd. and H1MP01-43 from Amicon, Inc. Beverly, MA) were used to recycle cells back to the fermentor.

Turbidostat Turbidity control consisted of a laser probe (LA-300LT, Automatic System Research Co. Ltd., Tokyo), installed in the fermentor, for online measurements of turbidity (Yamane, et al 1992). It was preset to control the cell density at specific concentrations as determined by a previous calibration between the cell concentration and culture turbidity.

Culture systems All fermentations, both batch and continuous, were carried out in a 1- $l$ jar fermentor with a working volume of $400 \mathrm{ml}$, maintained at $37^{\circ} \mathrm{C}$ and agitated at $400 \mathrm{rpm}$ without gas flow. The culture $\mathrm{pH}$ was controlled at 6.0 by addition of $10 \mathrm{M} \mathrm{NaOH}$ throughout the experiments. The batch fermentation setup consisted of a simple $\mathrm{pH}$-controlled system. The setup of the $\mathrm{pH}$-dependent continuous fermentation experiment has been shown in Fig. 1. The system was initially operated in batch mode and switched to continuous mode when the residual glucose concentration was about $2 \mathrm{~g} / \mathrm{l}$, during which biomass recycling and $\mathrm{pH}$-dependent feeding commenced simultaneously (Ishizaki and Vonktaveesuk, 1996). pH-dependent fresh medium feeding was achieved through separatc inflows for alkali and fresh medium controlled by changes

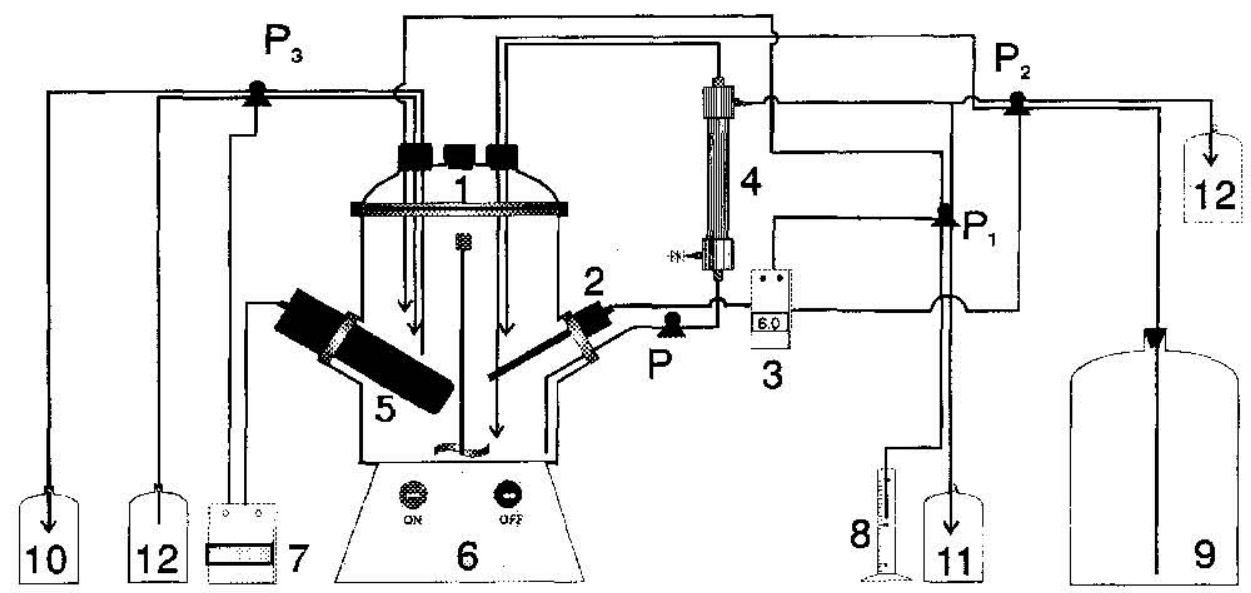

Fig. 1. Schematic Diagram of $\mathrm{pH}$-dependent feed control with turbidity control system.

key: 1. Fermentor; 2. $\mathrm{pH}$ electrode; 3. $\mathrm{pH}$ Conlroller; 4. Hollow fiber cartridge; 5. Turbidity probe; 6 . Magnetic stirrer; 7 . Turbidily controller; 8 . NaOH lank; 9 . Fresh medium reservoir; 10, 11. Feed-out tank; 12. Glucose free solution rescrvoir; and $\mathrm{P}, \mathrm{P}_{1}, \mathrm{P}_{2}, \mathrm{P}$ : Pump. 
in the $\mathrm{pH}$ of the culture broth (Tripetchkul, 1992). This was achicved via a control loop based on the $\mathrm{pH}$ of the culture broth and the preset upper and lower $\mathrm{pH}$ points. When the microorganism metabolized glucose and produced lactic acid, the $\mathrm{pH}$ in the culture fell below 6.0 and alkali was automatically pumped into the fermentor to neutralize the acid to maintain the preset point. As long as glucose was present, the $\mathrm{pH}$ drop and alkali feed was repeated until all remaining glucose was spent. When substrate is finally exhausted (glucose concentration below critical level), the $\mathrm{pH}$ of the culture is expected to rise. Substrate is fed at the upper preset point. At the preset cell density, the turbidity control system was started, by a feedback loop that consisted of the turbidity controller and the dilution system, by feeding of glucose-free solution. Fach inflow route was balanced by an outflow rate as shown in the Fig. 1. Therefore, the dilution rate (D) for this system was calculated based on the equation below:

$$
\mathrm{D}=\left(\mathrm{F}_{1}+\mathrm{F}_{2}+\mathrm{F}_{3}\right) / \mathrm{E} \quad \text { Eq. } 1
$$

where $F_{1}$ is the inflow rate of alkali into the fermentor (balanced by the outllow of cell-free effluent from the module by the pump $\left.P_{1}\right), F_{z}$ is the inflow rate of substrate into the fermentor (balanced by the outflow of cell-free effluent from the pump $\mathrm{P}_{2}$ ), $\mathrm{F}_{3}$ is the inflow rate of glucose-free solution into the fermentor for the dilution (balanced by the outflow of culture broth by the pump $\mathrm{P}_{3}$ ), and $\mathrm{V}$ is the total volume of the culture broth

Analytical methods Cell density was measured in terms of optical absorbance, at $562 \mathrm{~nm}$, in a spectrophotometer (UVIDEC-320; Japan Spectroscopic Co., Ltd., Tokyo.). Cell growth was determined using a pre-determined standard curve. Glucose and lactate concentrations were determined by HPLC (LC-10AD, RID $-6 \mathrm{~A}$ Refractive Index Detector, Shimadzu, Japan) using an Aminex HPX-87H column (Biorad, USA) at $50^{\circ} \mathrm{C}$ and $0.400 \mathrm{ml} / \mathrm{min}$ flow rate of $5 \mathrm{mM}$ sulfuric acid as a mobile phase.

\section{RESULTS AND DISCUSSION}

\section{Batch culture in glucose from sago starch}

In order to exploit sago starch as a feedstock for lactic acid production, we compared the batch culture kinetics of lactic acid production between glucose obtained from sago starch hydrolysis and technical grade glucose. The profiles of cell growth, glucose consumption and lactic acid production observed were similar. As shown in figure 2, the specific growth rate, glucose consumption rate and lactale productivity in the two media were almost identical. It was concluded that glucose obtained from sago starch hydrolysis could be used for fermentative lactic acid production. Following this work, we observed the kinetics of lactate production in $75 \mathrm{~g} / \mathrm{l}$ glucose (Fig. 3). Ohleyer et al (1985b) demonstrated that using $35 \mathrm{~g} / l$ as the initial glucose concentration, $35 \mathrm{~g} / l$ of lactic acid would be produced. This means that $100 \%$ of the glucose is converted into lactic acid. When a concentration of $85 \mathrm{~g} / \mathrm{l}$ was used, however, only a $70 \%$ conversion value was obtained. Additionally they found that using a glucose concentration of $60 \mathrm{~g} / \mathrm{l}, 100 \%$ conversion was again displayed. We obtained similar results when 30 and $75 \mathrm{~g} / \mathrm{l}$ of glucose were used. In general, lactate production was accompanied by a rapid drop in the $\mathrm{pH}$ of the culture and alkali was added to neutralize this effect. As shown in Fig. 3, the 


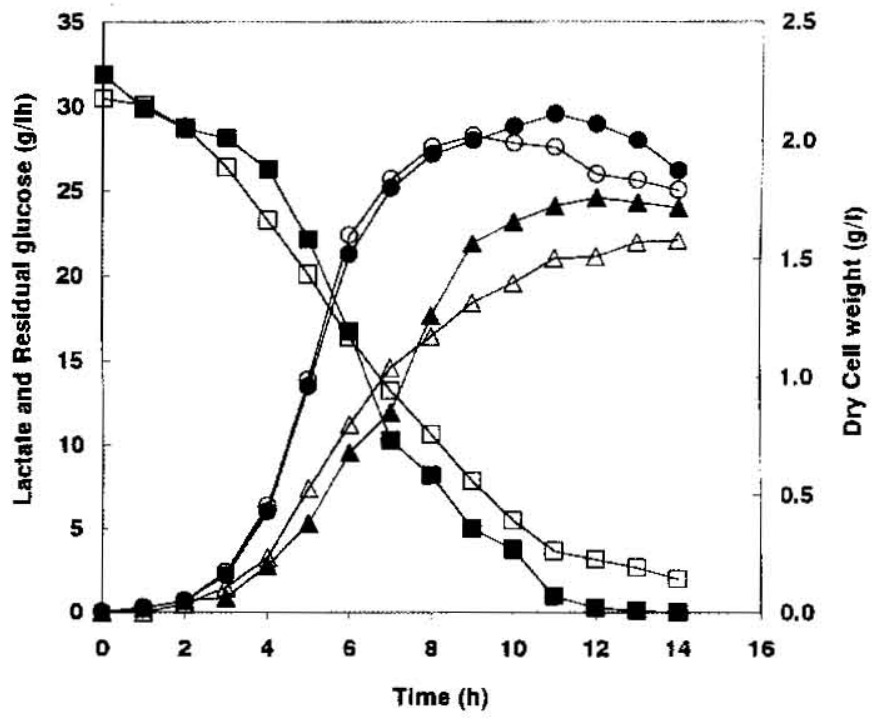

Fig. 2. Time course lactic acid fermentation of Lactococcus lactis IO-1 using commercial glucose (close symbols) and glucose from sago starch (opern symbols).

Symbols: $\boldsymbol{\square}$, Residual glucose; $\boldsymbol{\Delta}$, Lactate concentration in brolh, Dry Cell Weigh; $\square$, Residual glucose; $\Delta$, Lactate concentration in broth; $\mathrm{O}$, Dry Cell Weight.

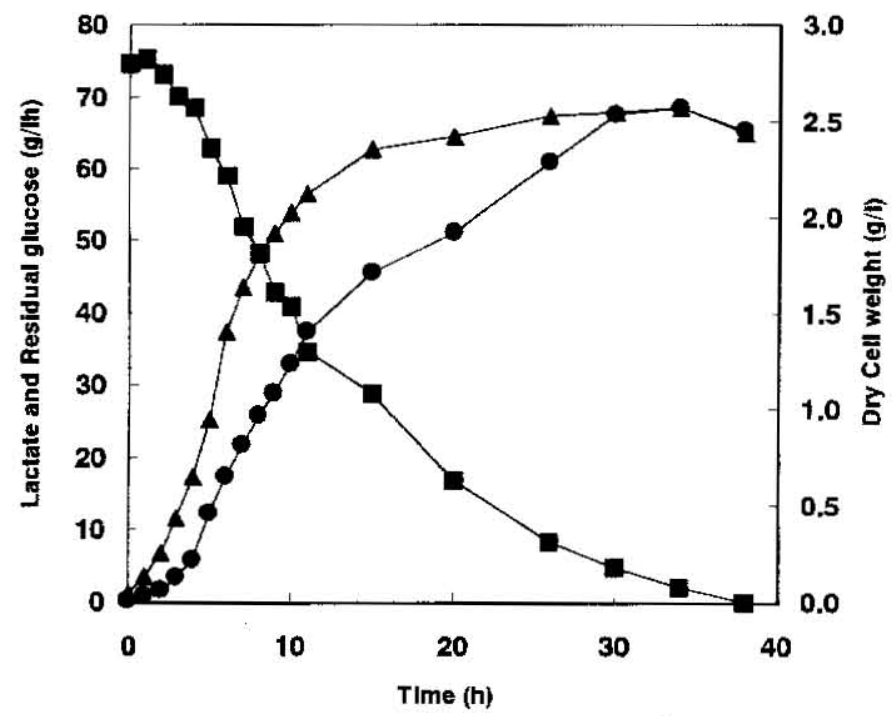

Fig. 3. Batch culture: lactic acid fermentation using an initial glucose concentration of $75 \mathrm{~g} /$.

Symbols: $\boldsymbol{\square}$, Residual glucose; $\boldsymbol{\Delta}$, Lactate concentration in broth; , Dry Cell Weight. 
maximum lactic acid concentration after $34 \mathrm{~h}$ was $68 \mathrm{~g} / \mathrm{l}$, with residual glucose levels at $2.0 \mathrm{~g} / \mathrm{l}$, and at $38 \mathrm{~h}$, ghucose had been consumed completely. It was also observed that a lactate concentration between $50-60 \mathrm{~g} / l$ resulted in the inhibition of cell growth. From these results we assumed that in continuous culture, using an iritial glucose concentration in the range of $50-65 \mathrm{~g} / l$, all the glucose could be converted to lactic acid.

\section{Continuous calture}

\section{Effect of cell density and dilution rate}

In continuous lactic acid fermentation, the two principal variables influencing volumetric productivity are the difution rate and the cell concentration. A high cell concentration obtained through cell recycling enhances lactic acid production. Therefore, the complimentary effects of high cell density and high dilution rate on lactate productivity were observed by varying the dilution rate between 0.21 and $1.1 \mathrm{~h}^{-1}$. Table 1 shows the variation of individual kinetic parameters at different cell concentrations and dilution rates. Generally, cell concentration and dilution rate were essential parameters in obtaining high productivities. Volumetric lactate productivity progressively increased from $8.2 \mathrm{~g} \cdot l^{-1} \cdot \mathrm{h}^{-}$at a dilution rate of $0.21 \mathrm{~h}^{-1}$ to $33.1 \mathrm{~g} \cdot \mathrm{l}^{-1} \cdot \mathrm{h}^{-1}$ at a dilution rate of $1.1 \mathrm{~h}^{-1}$. However, lactate concentration remained between 37 and $39 \mathrm{~g} / l$ until the dilution rate was increased to $1.1 \mathrm{~h}^{-1}$, when it decreased to $30 \mathrm{~g} / l$, while residual glucose concentration was low. Specific productivities in the range $0.31-0.2 \mathrm{~g} \cdot \mathrm{g}^{-1} \cdot \mathrm{h}^{-1}$ have been reported despite the high cell concentration employed (100-178 g/l) (Kamoshita et al, 1998). They conld not: obtain a lactic acid concentration of more than $50 \mathrm{~g} / \mathrm{l}$ using a stirred ceramic membrane reactor, due to problems encountered in membrane performance when operated at high cell density. From our results, it is clear that by increasing the cell concentration, it is possible to enhance the volumetric productivity and consequently the specific productivity. Using a cell concentration of $15 \mathrm{~g} /$, we obtained higher specific productivities to those obtained at higher cell concentrations (Bibal, el al. 1991, Meihaia and Cheryan, 1987a, Kamoshita, et at 1998). This was probably duc to our system which operated with high cell viability. We stated that the turbidity control system, which operated at low dilution rates, was responsible for the permission of high cell viability (data not shown).

\section{Effect of maintaining high cell density on lactic acid production and productivity}

The effect of using high cell dersity $(15 \mathrm{~g} / l)$ while maintaining the feed glucose concentration at $53 \mathrm{~g} / \mathrm{l}$ has been shown in Table 2 . The cell density was maintained at

Table 1. Kinetic parameters in run fermentations using $50 \mathrm{~g} / \mathrm{l}$ of glucose from Sago starch at different dilution rates and cell concentralions.

\begin{tabular}{lrrrrr}
\hline \multirow{2}{*}{ Parameter } & \multicolumn{5}{c}{ Dilution rate $\left(\mathrm{h}^{-1}\right)$} \\
\cline { 2 - 6 } & 0.21 & 0.44 & \multicolumn{1}{c}{0.5} & 0.75 & 1.1 \\
\hline Dry cell weight $(\mathrm{g} / \mathrm{l})$ & 4.6 & 5.0 & 6.0 & 10.0 & 15.3 \\
Residual glucose concentration $(\mathrm{g} / \mathrm{l})$ & 1.9 & 0.6 & 0.24 & 5.6 & 3.8 \\
Lactate concentration $(\mathrm{g} / \mathrm{l})$ & 39.2 & 36.8 & 38.6 & 36.8 & 30.1 \\
Volumetric lactate productivity $\left(\mathrm{g} \cdot \mathrm{l}^{-1} \cdot \mathrm{h}^{-1}\right)$ & 8.2 & 14.7 & 19.3 & 27.6 & 3.3 .1 \\
Spccific lactate productivity $\left(\mathrm{g} \cdot \mathrm{g}^{-1} \cdot \mathrm{h}^{\prime}\right)$ & 1.8 & 2.6 & 3.1 & 2.7 & 2.2 \\
\hline
\end{tabular}


Table 2. Kinctic parameters in rum fermentations using glucose from sago starch at different concentrations and different dilution rates.

\begin{tabular}{lrrrr}
\hline \multirow{2}{*}{ Parameter } & \multicolumn{4}{c}{ Dilution ratc $\left(\mathrm{h}^{1}\right)$} \\
\cline { 2 - 5 } & 0.35 & \multicolumn{1}{c}{0.5} & \multicolumn{1}{c}{0.21} & 0.7 \\
\hline Initial glucose concentration $(\mathrm{g} / \mathrm{l})$ & 53.0 & 53.0 & 64.0 & 64.0 \\
Dry cell weight $(\mathrm{g} / \mathrm{l})$ & 15.0 & 15.0 & 15.0 & 15.0 \\
Residual glucose concentration $(\mathrm{g} / \mathrm{l})$ & 0.8 & 5.1 & 2.7 & 12.2 \\
Lactate concentration $(\mathrm{g} / \mathrm{l})$ & 42.6 & 38.3 & 59.1 & 46.2 \\
Volumetric lactate productivity $\left(\mathrm{g} \cdot \mathrm{l}^{-1} \cdot \mathrm{h}^{-1}\right)$ & 14.9 & 19.2 & 12.4 & 32.3 \\
Specific lactate productivity $\left(\mathrm{g} \cdot \mathrm{g}^{-1} \cdot \mathrm{h}^{-1}\right)$ & 1.0 & 1.1 & 0.82 & 2.1 \\
\hline
\end{tabular}

$15 \mathrm{~g} / \mathrm{l}$ to minimize the fouling of the membrane, encountered in these processes. At dilution rates of 0.35 and $0.5 \mathrm{~h}^{-1}$ lactate concentration increased to 42.6 and $38.3 \mathrm{~g} / \mathrm{h}$, which corresponded to volumetric productivities of 14 and $19.1 \mathrm{~g} \cdot \mathrm{l}^{-1} \cdot \mathrm{h}^{-1}$ respectively. At a dilution rate of $0.35 \mathrm{~h}^{-1}$, lactate productivity was comparable to that shown at $0.44 \mathrm{~h}^{-1}$, using a cell concentration of $5 \mathrm{~g} / \mathrm{l}$ (Table 1 ), but the specific productivity and lactate concentration were higher. Taking into account the results obtained in batch culture with regards to glucose and lactic acid inhibition, we increased the initial glucose concentration to $64 \mathrm{~g} / \mathrm{l}$. As we have shown in Table 2, when dilution rate was $0.21 \mathrm{~h}$ ', a lactic acid concentration of $59.1 \mathrm{~g} / l$ was obtained and this corresponds to a volumetric productivity of $12.4 \mathrm{~g} \cdot 1^{1} \cdot \mathrm{h}^{\prime}$. The higher lactic acid concentration obtained was mainly due to the fact that we used a low dilution rate. Therefore we reasoned that, at this dilution rate. Lactococcus lactis $\mathrm{IO}-1$ used glucose mainly for producing lactic acid but not for growing while sustaining its lactate production rate and maintaining a high glucose conversion rate of $97 \%$. When dilution rate was increased to $0.7 \mathrm{~h}^{1}$, a lactate concentration of $46.2 \mathrm{~g} / \mathrm{l}$ was obtained, which corresponds to a productivity of $32.3 \mathrm{~g} \cdot l^{-1} \cdot \mathrm{h}^{-1}$. This productivity was similar to that obtained when dilution rate was $1.1 \mathrm{~h}^{1}$ (table 1). From these results it is clear that initial glucose concentration, dilution rate and cell concentration all play an important role in enhancing the lactate productivity. Ohleyer $e$ t al (1985b) reported a volumetric productivity of $151 \mathrm{~g} \cdot l^{-1} \cdot \mathrm{h}^{-3}$ using Lactobacillus delbrueckit, lactose as the substrate, a high dilution rate of $2.55 \mathrm{~h}^{1}$ and a cell concentration of $118 \mathrm{~g} / l$. However, the fermentation was sustained for orly 18 hours. This is disadvantageous from the point of view of an industrial-scale operation. The specific lactate productivity $\left(1.28 \mathrm{~g} \cdot \mathrm{g}^{\prime} \cdot \mathrm{h}^{\prime}\right)$ obtained by Ohlcyer et al, was lower comparing it with our results (Table 1). Both product concentration and productivity are essential parameters that determine the competitiveness of the production process. We are therefore focusing on improving the cell concentration so that lermentation could be operated at high dilution rates.

\section{REFERENCES}

Atkinson, B. and F., Mavituna 1991 Industrial Microbial processes, In "Biochemical Engineering and Biotechnology Handbook", $2^{\text {mil }}$ edn., ed. by Atkinson, B., and Mavituna, F. Macmillan, New York, pp. 1181-1183 
Bibal, B. Y.,Vayssier, G., Goma, and A., Pareillenx. 1991 High concentration cultivation of Lar:tococcus cremoris in a cell recycle reactor. Biotechnol. Bioeng., 37: 746-754

Boniardi, N., R., Rota, G., Nano. and B., Mazza, 1997 Lactic acid production by electrodialysis part. I: Experimental tests. J. Appt. Electrochemn., 27: 125-133

Chatterjec, M., S. L., Chakrabarty, B. D., Chatlopadhyay, and R. K., Mandal. 1997 Production of lactic acid by direct fermentation of starchy wastes by an amylase-producing Lactobacillus. Biotechnol. lett., 19: $873-874$

Datta, R., S. P., Tsai, P., Bonsignorc, S. H., Moon, and J. H., Frank. 1995 Technology and economic potential of poly (lactic acid) and lactic acid derivatives. FEMS Microbiol. Reo., 16: 221-231

Lvangelista, R. L., A. J. Mangold, and Z. L., Nikolov. 1994 Recovery of lactic acid by sorption: Resin evaluation. Appl. Microbiol. Bicchern. Biotechnol, 45/46: 131. 144.

Holvendahl, K. and B., Hahn-Hägerdal. 1997 L-lactic acid production from whole-wheat flour hydrolysate using strains of Lactobacilli and Lactococci. Enz, Microbiol. Technol., 20: 301-207

Ishizaki, A. 1997. Solution of environmental problems trough biomass conversion using microbial lechinology. In "Fuels and Chemicals from Biomass", cd. by Saha, B. C. and Woodward, J., ACS Symposium series 666, Washington DC., pp. 336-344.

Ishizaki, A. and P. Vonktavecsuk, 1996 Optimization of substrate feed for continuous production of lactic. acid by Lactococcus lactis: 10-1. Biotechnol. Let., 18: 1113-1118

Ishizaki, A., K., Osajima, K., Nakamura, K., Kimura, T., Hara, and T., Ezaki 1990 Biochemical characterization of Lactococcus lactis IO-1 whose optimum temperature is as high as $37^{\circ} \mathrm{C}$ T. $J$. Gen. Appl. Microbiol., 36: $1-6$

Karnoshita, Y., R., Ohashi, and T., Suzuki. 1998 Improvement of filtration performance of stirred ceramic membrane reactor and its application to rapid fermentation of lactic acid by dense cell culture of Lactococcus lactis. J. Femment. Bioeng., 4: 422-427

Linko, Y. Y and P., Janavaincn. 1996 Simultaneous liquefaction, saccharafication, and lactic acid fermentation on barley starch. Enz. Microbiol. Technol., 19: 118-123

Marshall, MA. Lactic acid bacteria: starter for flavor. 1987 FEMS Microbiol. Rev., 46: 327--336

Mchaia, M. A and M., Cheryan. 1987a Inmobilization of Lactobacillus bulgaricus in a hollow-fiber bioreactor for production of lactic acid from acid whey permeate. App. Biochem. Biotechnol., 14: $21-27$

Meihaia, M. A and M., Cheryan. 1987b Production of lactic acid from sweel whey permeates. Process Biochem., 22: $185-188$

Moldes, A. B., J. L., Alonso, and J. C., Parajó. 1999 Cogeneration of cellobiose and glucose from pretreated wood and bioconversion to lactic acid: a kinetic study. J. Biosci. Bioeng., 87: 787-792

Ohleyer, E., H. W., Blanch, and C. R.,Wilke, $1985 \mathrm{a}$ Continuous production of lactic acid in a cell recycle reactor. Appl Biochem. Biotechnol., 11: 317-332.

Ohleyer, E., C. R., Wilke, and H. W., Blanch. 1985 b Continuous production of lactic aciid from glucose and lactose in a cell recycle reactor. Appl. Biochem. Biotechnol., 11: 457-463

Senthuran, A.; V.; Senthuran, B., Mattiassorl, and R., Kaul., 1997 Lactic acid fermenlátion in a rccycle batch reactor using immobilized Lactobacillus casei. Biotcchnol. Bioeng., 55: 811-853

Tripetchkul, S., M., Tonokawa, and A., Ishizaki. 1992 Ethanol production by Zymomonas mobilis using natural rubber wastes as a nutritional source. J. Ferment. Biotechnol., 74: 384-388

Tripetchkul, S. 1993.. Development of the medium for utilization of renewable resource and computer controlled continuous culture system for bacterial ethanol fermentation employing Zymomonas mobilis. Ms. C. Thesis of Kyushu University.

Vick Roy, TB. 1985 Lactic Acid. In "The practice of biotechnology: commodily products", Vol. 3, ed. by Blanch, H. W., Drew, S., Wang, D. I. C. Pergamon Press, Elmsford, NY, pp. 761-776

Vonktaveesuk, P., M. Tonokawa, and A., Ishizaki. 1994 Stimulation of the rate of L-fermentation using Lactococcus kaxtis $10-1$ by periodic electrodialysis,, J. Ferment. Bioeng., 77: 508-512.

Xavier, A. M. R. B., L. M. D., Gonçalkes, J. C., Morcira, and M. J. T., Carrondo. 1995 Operational patterns affecting lactic acid production in ultrafiltration cell recycle reactors. Biotechnol. Bioeng., $\mathbf{4 5 :}$ $320-327$

Yamane, T., W., Hibino, K., Ishihara, Y., Kadotani, and M., Kominami, 1992 Feed-batch culture automated by uses of continuously measured ccll concentration and culture volume. Biolechnol. Bioeng., 39: 550-555 
Ye, K., S., Yin, and K., Shimizu. 1996 Perfomance improvernent of lactic acid fermentation by multistage: extrative fermentation, J. Ferment. Bioeng., 81: 240-246.

Yin, P., K., Yahiro, T., Ishigaki, Y., J'ark, and Y., Okabe. 1987 L (+)-Iactic acid production by repeated batch culture of Rhizopus oryzae in airlift biorcactor. FEMS Miorotiol. Rev, 46: 32 7-336

Tayed, G. and J., Winter. 1935 Batch and continuous production of lactic acid from salt whey using free and inmobilized cultures of lactobacilli. Appl Microbiol Biotechnot., 44: 362-366 